\title{
LOW GENETIC DIVERSITY AMONG GARLIC (Allium sativum L.) ACCESSIONS DETECTED USING RANDOM AMPLIFIED POLYMORPHIC DNA (RAPD)
}

\author{
Mario Paredes C. ${ }^{\text { }}$, Viviana Becerra V. ${ }^{1}$, and María I. González A. ${ }^{1}$
}

\begin{abstract}
A B S T R A C T
Garlic (Allium sativum L.) is a species of vegetative propagation, showing high morphological diversity. Besides, its clones have specific adaptations to different agroclimatic regions. The objective of this study was to determine the genetic diversity of 65 garlic clones collected in Chile and introduced from different countries, by using RAPD (Random Amplified Polymorphic DNA). Fourty random primers of 10 mers generated a total of 398 bands with an $87 \%$ of polymorphism. Each primer amplified between two and 20 bands. The size of the fragments obtained fluctuated between 3200 and $369 \mathrm{bp}$. The results showed that the clones analyzed had a genetic similarity rate of $94 \%$. In addition, $70 \%$ of them were clustered in one major group. However, in spite of that situation several clones have different agronomic characteristics.
\end{abstract}

Key words: Allium sativum, germplasm, genetic diversity, RAPD diversity.

\section{INTRODUCTION}

Botanically, garlic belongs to the genus Allium, family Alliaceae, which includes important vegetable crop such as onion (Allium cepa), leek (A. ampeloprasum) and shallots (A. ascalonicum). Garlic is a diploid species $(2 \mathrm{n}=2 \mathrm{x}=16)$ of obligated apomixis, therefore its reproduction is vegetative (McCollum, 1987; Figliuolo et al., 2001; Ipek et al., 2003 ; 2005). Its primary center of origin is Central Asia (Kazakhstan), and the secondary center is the Mediterranean and Caucasus zones (Etoh and Simon, 2002).

The value of garlic as a crop has been recognized from very ancient times; it is estimated that it has been cultivated for over 5000 years. During all this time it has been used as food, condiment and medicine by many civilizations in Asia and the Mediterranean region (Ipek et al., 2005). The DNA content of garlic is $32.7 \mathrm{pg}$ per $2 \mathrm{C}$ nucleus, which is one of the largest genomes among cultivated crops (Ranjekar et al., 1978, Ipek et al., 2005), and with a wide kariotype variation (Jones and Rees, 1968). The garlic genome has low guanine-citocine (GC) content and a large amount of repetitive DNA (Kirk et al., 1970). The first two low density genetic map generated by self-pollination of unrelated plants consisting of amplified fragment length polymorphism (AFLPs) and gene-specific markers spanned 1166 cM and $862 \mathrm{cM}$, respectively (Ipek et al., 2005).

\footnotetext{
${ }^{1}$ Instituto de Investigaciones Agropecuarias, Centro Regional de Investigación Quilamapu, Casilla 426, Chillán, Chile. E-mail: mparedes@inia.cl *Corresponding author. Received: 26 April $2007 . \quad$ Accepted: 6 August 2007.
} 
The different garlic species are classified in four groups: longicuspis, ophioscorodon, sativum, subtropical and the pekinense sub-group. The longicuspis group is considered the oldest and it is postulated to be the original group. The ophioscorodon group is distributed in Central Asia, the sativum group in the Mediterranean zone and the $s u b$ tropical in the south and southeast of Asia. Finally, the pekinense subgroup comes from the east of Asia (Maaß and Klaas, 1995).

In spite of its infertility, garlic shows wide morphological and agronomic variations in characteristics such as color and size of the bulb, plant height, flowering, number and size of the cloves, days to harvesting, resistance to storage capacity, dormancy and adaptation to agroclimatic conditions (Pooler and Simon, 1993b; del Pozo et al., 1997; Lallemand et al., 1997; Lopez et al., 1997; Matus et al., 1998; Figliuolo et al., 2001).

The analysis of the morphologic and physiologic variability of garlic has allowed for a subdivision of the A. sativum species into two horticultural groups: sativum (common or Mediterranean garlic) and ophioscorodon (Asiatic garlic) (Jones and Mann, 1963; Hanelt, 1990). Later on, these two groups were called subspecies, which in turn they were divided into diverse groups or varieties. The ophioscorodon subspecies generally develops floral stalks and includes two varieties: 'Rocambole' and 'Continental'. The sativum subspecies does not develop floral stalks and it has three sub-groups: 'Artichoke', 'Silverskin' and 'Asiatic' (Etoh and Simon, 2002).

The characterization of garlic germplasm has been based mainly on phenotypic characteristics. However, morphological characteristics can vary under different agroclimatic conditions. This situation adds complexity to the characterization of garlic clones (Bradley et al., 1996; Al-Zahim et al., 1997). To eliminate some of these limitations, biochemical (Pooler and Simon, 1993a; Lallemand et al., 1997) and molecular markers (Wilkie et al., 1993; Bark, and Havey, 1995; Maa $\beta$ and Klaas, 1995; D'Ennequin et al., 1997; Dubouzet and Shinoda, 1999; García Lampasona et al., 2003; Volk et al., 2004; RosalesLongo et al., 2007, Ovesna et al., 2007) have been used in genetic diversity studies of this species.
At present, the Instituto de Investigaciones Agropecuarias (INIA) has a collection of naturalized and introduced garlic clones, coming from diverse agroclimatic zones. This germplasm has been evaluated for its agronomic and physiologically characteristics (Del Pozo et al., 1997; Matus et al., 1998), and to select material adapted to different agroecological conditions.

The objective of this study was to determine the genetic diversity of the garlic clones maintained ex situ in the Germplasm Bank at INIA, by means of RAPD (Random Amplified Polymorphic DNA).

\section{MATERIALS AND METHODS}

\section{Plant material}

Sixty-five garlic clones from the INIA's Germplasm Bank, maintained at the Santa Rosa Experimental Station, Chillán $\left(36^{\circ} 36^{\circ} \mathrm{S} ; 7^{\circ} 06^{\circ} \mathrm{W}\right)$ were evaluated. This collection of genotypes contains clones collected in the country and others introduced from different regions of the world (Table 1).

\section{Method}

DNA extraction. The total DNA was extracted from healthy leaves, previously stocked at $-85^{\circ} \mathrm{C}$. The samples were grinded in liquid nitrogen and incubated at $65{ }^{\circ} \mathrm{C}$ during 1 hour using the SDS extraction buffer, pH 9.5 (Tris $50 \mathrm{mM}, \mathrm{NaCl} 0.7$ M, EDTA 10 mM, SDS 1\%, $\beta$-mercaptoethanol 1\% and PVPP 5\%) (Becerra-Velásquez and Gepts, 1994). The samples were then centrifuged at 5000 rpm to separate the phases. The water phase was extracted twice with chloroform:isoamyl alcohol (24:1) and centrifuged at $5000 \mathrm{rpm}$ during $15 \mathrm{~min}$. DNA was precipitated with isopropanol and the DNA pellet was washed in $76 \%$ alcohol and ammonium acetate $(10 \mathrm{mM})$. The pellet was finally dried and suspended in TE (Tris $10 \mathrm{mM}$, EDTA $1 \mathrm{mM}$, $\mathrm{pH}$ 8.0). The DNA was quantified in a fluorometer (DyNA Quant ${ }^{\mathrm{TM}}$ 200. Hoeffer, San Francisco, USA) and the samples were diluted to $5 \eta \mathrm{g} \mu \mathrm{L}^{-1}$. An electrophoresis in agarose $1 \%$ was carried out to verify the DNA quality, using $\lambda$ HindIII as a standard for the size of fragments.

Genetic characterization. The genetic characterization was carried out by using 40 RAPDs primers (10 mers) belonging to OPA 01-20 and OPB 
Table 1. Allium sativum accessions analyzed by Random Amplified Polymorphic DNA (RAPD).

\begin{tabular}{|c|c|c|c|c|c|}
\hline $\mathrm{N}^{\circ}$ acc. & Clone & Country of origin & Collection site / region & Latitude & Longitude \\
\hline 2 & Taiwan Kakis & USA & Llay-Llay & $32^{\circ} 50^{\prime}$ & $70^{\circ} 56^{\prime}$ \\
\hline 3 & México Blanco Kakis A & Mexico & Llay-Llay & $32^{\circ} 50^{\prime}$ & $70^{\circ} 56^{\prime}$ \\
\hline 4 & Lluteño & Chile & Lluta & $18^{\circ} 30^{\prime}$ & $70^{\circ} 20^{\prime}$ \\
\hline 5 & Mexicano Criollo Kakis A & Mexico & Llay-Llay & $32^{\circ} 50^{\prime}$ & $70^{\circ} 56^{\prime}$ \\
\hline 6 & Taiwan Básico & Mexico & Llay-Llay & $32^{\circ} 50^{\prime}$ & $70^{\circ} 56^{\prime}$ \\
\hline 7 & Nirivilo & Chile & Constitución & $35^{\circ} 19^{\prime}$ & $72^{\circ} 25^{\prime}$ \\
\hline 8 & Talca & Chile & Constitución & $35^{\circ} 19$ & $72^{\circ} 25^{\prime}$ \\
\hline 9 & Mexicano Criollo Kakis B & USA & Llay-Llay & $32^{\circ} 50^{\prime}$ & $70^{\circ} 56^{\prime}$ \\
\hline 10 & Mexicano Blanco Basico & USA & Llay-Llay & $32^{\circ} 50^{\prime}$ & $70^{\circ} 56^{\prime}$ \\
\hline 11 & Egipcio Básico & USA & Llay-Llay & $32^{\circ} 50^{\prime}$ & $70^{\circ} 56^{\prime}$ \\
\hline 13 & Constitución & Chile & Constitución & $35^{\circ} 19^{\prime}$ & $72^{\circ} 25^{\prime}$ \\
\hline 14 & Blanco Maipú & Chile & Llay-Llay & $32^{\circ} 50^{\prime}$ & $70^{\circ} 56^{\prime}$ \\
\hline 15 & Blanco Mendoza & Chile & Llay-Llay & $32^{\circ} 50^{\prime}$ & $70^{\circ} 56^{\prime}$ \\
\hline 16 & Blanco Camiña & Chile & Camiña & $19^{\circ} 18^{\prime}$ & $69^{\circ} 25^{\prime}$ \\
\hline 17 & Rojo Maipú & Argentine & Maipo & $33^{\circ} 43^{\prime}$ & $70^{\circ} 47^{\prime}$ \\
\hline 18 & Rosado Nortino I R & Chile & Arica & $18^{\circ} 29^{\prime}$ & $70^{\circ} 17^{\prime}$ \\
\hline 19 & Rosado Camiña & Chile & Camiña & $19^{\circ} 18^{\prime}$ & $69^{\circ} 25^{\prime}$ \\
\hline 20 & Morado Ariqueño & Chile & Arica & $18^{\circ} 29^{\prime}$ & $70^{\circ} 17^{\prime}$ \\
\hline 21 & Rosé de Lautrec & France & Paine & $33^{\circ} 49^{\prime}$ & $70^{\circ} 45^{\prime}$ \\
\hline 22 & Morado Ruso & Chile & Temuco & $38^{\circ} 43^{\prime}$ & $72^{\circ} 34^{\prime}$ \\
\hline 23 & Rosado Copiapino & Chile & Copiapó & $27^{\circ} 21$ & $70^{\circ} 20^{\prime}$ \\
\hline 24 & Messidrome & France & Paine & $33^{\circ} 49^{\prime}$ & $70^{\circ} 45^{\prime}$ \\
\hline 25 & Antofagasta & Chile & Calama & $22^{\circ} 26^{\prime}$ & $68^{\circ} 55^{\prime}$ \\
\hline 26 & Quepe & Chile & IX Región & $38^{\circ} 52^{\prime}$ & $72^{\circ} 36^{\prime}$ \\
\hline 27 & Carrarreñi & Chile & IX Región & - & - \\
\hline 28 & Los Boldos & Chile & IX Región & $39^{\circ} 08^{\prime}$ & $73^{\circ} 07^{\prime}$ \\
\hline 29 & Pircunche & Chile & IX Región & - & - \\
\hline 30 & El Palqui & Chile & El Palqui & - & - \\
\hline 31 & Rosado Argentino & Argentine & Llay-Llay & $32^{\circ} 50^{\prime}$ & $70^{\circ} 56^{\prime}$ \\
\hline 32 & Blanco Argentino Ocoa & Argentine & Llay-Llay & $32^{\circ} 50^{\prime}$ & $70^{\circ} 56^{\prime}$ \\
\hline 33 & CAR & Chile & Chillán & $36^{\circ} 35^{\prime}$ & $72^{\circ} 06^{\prime}$ \\
\hline 34 & Camiña Vallenar & Chile & Vallenar & $28^{\circ} 34^{\prime}$ & $71^{\circ} 45^{\prime}$ \\
\hline 35 & Chile Chico & Chile & X Región & $46^{\circ} 32^{\prime}$ & $71^{\circ} 43^{\prime}$ \\
\hline 36 & Rosado Chileno & Chile & Llay-Llay & $32^{\circ} 50$ & $70^{\circ} 56^{\prime}$ \\
\hline 37 & Imperial & Chile & IX Región & $38^{\circ} 44^{\prime}$ & $72^{\circ} 57^{\prime}$ \\
\hline 38 & Chol Chol & Chile & IX Región & $38^{\circ} 36^{\prime}$ & $72^{\circ} 50^{\prime}$ \\
\hline 39 & Uruguay GLB & Uruguay & Chillán & $36^{\circ} 35^{\prime}$ & $72^{\circ} 06^{\prime}$ \\
\hline 40 & Cato & Chile & Chillán & $36^{\circ} 35^{\prime}$ & $72^{\circ} 06^{\prime}$ \\
\hline 42 & Uruguay $1 \mathrm{~A}-2$ & Uruguay & Chillán & $36^{\circ} 35^{\prime}$ & $72^{\circ} 06^{\prime}$ \\
\hline 43 & Uruguay $1 \mathrm{~A}-12$ & Uruguay & Chillán & $36^{\circ} 35^{\prime}$ & $72^{\circ} 06^{\prime}$ \\
\hline 44 & Uruguay LB-13 & Uruguay & Chillán & $36^{\circ} 35^{\prime}$ & $72^{\circ} 06^{\prime}$ \\
\hline 45 & Rosado Chillán & Chile & Chillán & $36^{\circ} 35^{\prime}$ & $72^{\circ} 06^{\prime}$ \\
\hline 46 & Arica & Chile & Arica & $18^{\circ} 29^{\prime}$ & $70^{\circ} 17^{\prime}$ \\
\hline 47 & Rosado Criollo Iscayachi & Bolivia & Tarija & $21^{\circ} 31^{\prime}$ & $64^{\circ} 44^{\prime}$ \\
\hline 48 & Rosado Marfil Criollo & Bolivia & Tarija & $21^{\circ} 31$ & $64^{\circ} 44^{\prime}$ \\
\hline 49 & Rosado INIA & Spain & Tarija & $21^{\circ} 31$ & $64^{\circ} 44^{\prime}$ \\
\hline 50 & Rosado Palqueño & Bolivia & Tarija & $21^{\circ} 31$ & $64^{\circ} 44^{\prime}$ \\
\hline 51 & Rosado Argentino Iscayachi & Bolivia & Tarija & $21^{\circ} 31^{\prime}$ & $64^{\circ} 44^{\prime}$ \\
\hline 52 & Chino & China & Llay-Llay & $32^{\circ} 50^{\prime}$ & $70^{\circ} 56^{\prime}$ \\
\hline 53 & Rojo Peruano & Chile & Arica & $18^{\circ} 29^{\prime}$ & $70^{\circ} 17^{\prime}$ \\
\hline 54 & Egipto & Chile & Llay-Llay & $32^{\circ} 50^{\prime}$ & $70^{\circ} 56^{\prime}$ \\
\hline 55 & Centenario & Brazil & Brasilia & - & - \\
\hline 56 & Río Grande Calama & Chile & Calama & $22^{\circ} 26^{\prime}$ & $68^{\circ} 55^{\prime}$ \\
\hline 57 & Calle Chica & Chile & Calama & $22^{\circ} 26^{\prime}$ & $68^{\circ} 55^{\prime}$ \\
\hline 58 & Blanco Andino & Chile & Calama & $22^{\circ} 26^{\prime}$ & $68^{\circ} 55^{\prime}$ \\
\hline 59 & Ruso Coyhaique & Chile & Temuco & $38^{\circ} 43^{\prime}$ & $72^{\circ} 34^{\prime}$ \\
\hline 61 & Fukuchi White & Japan & Japan & - & - \\
\hline 62 & California Late & USA & USA & - & - \\
\hline 63 & Blanco El Natre & Chile & Araucanía & - & - \\
\hline 64 & Blanco Imperial & Chile & Araucanía & $38^{\circ} 44^{\prime}$ & $72^{\circ} 57^{\prime}$ \\
\hline 65 & Blanco Nahuelbuta & Chile & Araucanía & - & - \\
\hline 66 & Blanco Araucano & Chile & Araucanía & - & - \\
\hline 67 & Huichahue & Chile & Araucanía & - & - \\
\hline 68 & Blanco Cañete & Chile & Cañete & $37^{\circ} 48^{\prime}$ & $73^{\circ} 24^{\prime}$ \\
\hline 69 & Rondadero & Chile & Chillán & $36^{\circ} 35^{\prime}$ & $72^{\circ} 06^{\prime}$ \\
\hline
\end{tabular}

IX Region: Region of La Araucanía; X Region: Region of Los Lagos. 
01-20 series (Operon Technologies, Alameda, California, USA). The amplification conditions were optimized until a high reproducibility of the band patterns was obtained. The final reaction volume was $25 \mu \mathrm{L}$, which contained $10 \mathrm{mM}$ Tris$\mathrm{HCl}, \mathrm{pH} 8.3,1.0 \mathrm{mM} \mathrm{MgCl} 2,50 \mathrm{mM} \mathrm{KCl}, 0.4 \mu \mathrm{M}$ primers, 1 unit of Taq-polimerase (Invitrogen, Carlsbad, California, USA), $0.05 \mathrm{mM}$ dNTPs and $25 \eta \mathrm{g}$ DNA template.

The amplification conditions were as follows: three initial cycles at $95^{\circ} \mathrm{C}$ for $1 \mathrm{~min}, 48^{\circ} \mathrm{C}$ for $1 \mathrm{~min}, 72$ ${ }^{\circ} \mathrm{C}$ for 2 min, continuing with 40 cycles at $94{ }^{\circ} \mathrm{C}$ for $30 \mathrm{~s}, 48{ }^{\circ} \mathrm{C}$ for $40 \mathrm{~s}, 72{ }^{\circ} \mathrm{C}$ for $2 \mathrm{~min}$, and an extension period of $72{ }^{\circ} \mathrm{C}$ for $10 \mathrm{~min}$ (PTC-220 Thermocycler, MJ Research, Watertown, Massachussets, USA). The amplification product was separated by electrophoresis in agarose gels $(2 \%)$ in $1 \mathrm{X} \mathrm{TAE}$ (Tris acetate $40 \mathrm{mM}$, EDTA $1 \mathrm{mM}, \mathrm{pH} 8.0$ ) at $100 \mathrm{~V}$ for $3.5 \mathrm{~h}$, followed by ethidium bromide staining. The gels were visualized and photographed under ultraviolet light for their evaluation (Transluminator MacroVue ${ }^{\mathrm{TM}}$, Hoefer, San Francisco, California). All amplifications were duplicated to verify the stability of the results.

Data analysis. Only reproducible bands were considered to evaluate the results. Each band was considered as an independent attribute and was accounted for qualitatively by its presence (1) or absence $(0)$ generating a binary matrix. The genetic similarity between genotype pairs was estimated using the Jaccard similarity coefficient with the SIMQUAL option. The similarity matrix was calculated by means of sequential, agglomerative, hierarchical and nested clustering (SAHN) (Sneath and Sokal, 1973). The dendrogram was generated by the hierarchical method and the UPGMA grouping algorhythm. The COPH option was used to generate a matrix of cophenetic values. The MXCOMP option of this matrix was used to calculate the correlation between the cophenetic correlation matrix and the original grouping matrix (SIMQUAL). This analysis measures if the original data are represented in the grouping analysis with 1000 permutations, which generates a cophenetic correlation value (r). It is considered that a correlation value of $r=0.9$ shows a good adjustment (Mantel, 1967). These analyses were made using the NTSYSpc 2.1 program (Rohlf, 2000).

\section{RESULTS AND DISCUSSION}

Vegetative propagation of garlic has been used for many centuries; therefore the presence of genetically closely related clones and the presence of duplications in the germplasm banks are two facts that can be taken into account. A molecular marker such as RAPD, which does not require prior information from DNA sequences of the species, could be very useful to evaluate the genetic diversity of the garlic clones currently available at INIA's Germplasm Bank.

In this study, the analysis of the 40 RAPD primers generated a total of 398 bands, of which $87 \%$ detected polymorphism. The total number of bands per primer ranged between 2 (OPA-4) and 20 (OPA19), and with a molecular size between 3200 and 369 pairs of bases (pb) according to the $\lambda$ Hind III as a molecular standard (Figure 1).

Due to the large number of bands which detected polymorphism (346) in this analysis, it can be said that the RAPDs gave a good approximation of the genetic relationship existing among the evaluated clones. It is assumed that the amplified DNA fragments (amplicons) that co-migrate in the different accessions are similar in their sequences. Wilkie et al. (1993) isolated and analyzed several common RAPDs garlic bands and analyzed their homology by means of a DNA hybridization process under two types of astringency, low and medium-high. The results obtained indicated that all the common RAPDs bands isolated of similar intensity showed high homology. However, in the gel some of these common bands showed signals of hybridization of different strength, which would indicate the existence of some differences in sequences homology. Another study, carried out on garlic using AFLP amplicons, pointed out that $95.4 \%$ of the fragments analyzed had a high homology rate at DNA sequences level (Ipek et al., 2006), and that the possibly errors in the sequence homology of the RAPDs amplicons was due to chance, and that their effect was very slight upon the average similitude of genotypes of Brassica and Helianthus analyzed (Adams and Rieseberg, 1998). To avoid this problem, only the bands showing similar intensity, consistent and clear, were used in the genetic analysis of the amplification products. 

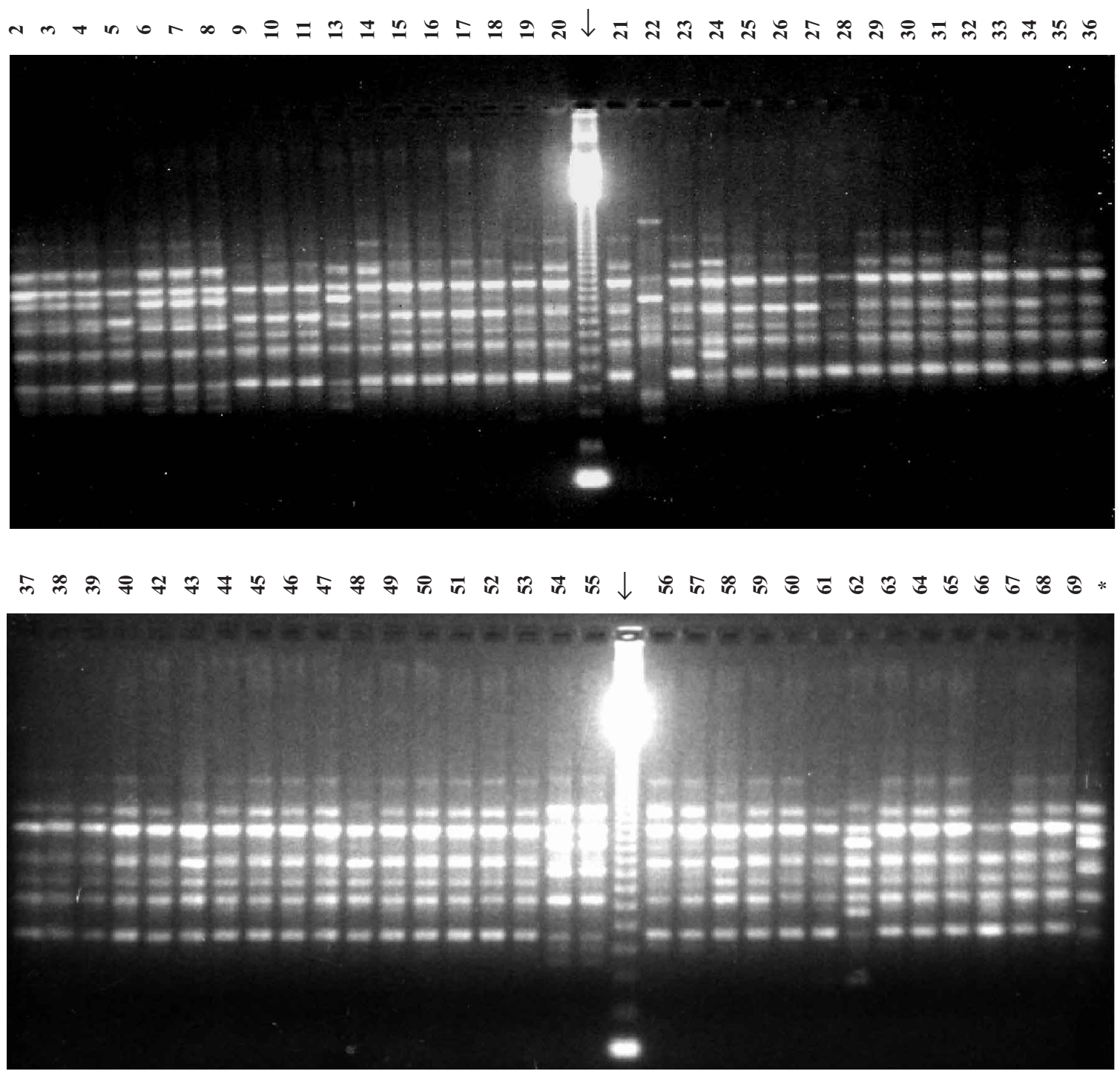

Figure 1. Banding pattern of 65 Allium sativum clones generated with OPA-11 Random Amplified Polymorphic DNA (RAPD) primer and ladder $(\downarrow)$ of $123 \mathrm{bp.}$

* Allium ampeloprasum $\mathrm{L}$

RAPDs analysis indicated that there is little genetic diversity among the clones analyzed (Figure 2) in spite of a high number of bands that detected polymorphism. This situation might be due to the fact that most of these polymorphic bands showed a low frequency in the genotypes evaluated. The coefficients of similarity of the analyzed genotypes generated a dendrogram that grouped the accessions into two main clusters. The first group included a total of 44 clones $(68 \%)$. This group is homogeneous, with a $100 \%$ of genetic similarity for the RAPD primers analyzed and included clones from different geographical origins.

This cluster includes clones which emit a floral stalk (Rosado Argentino Iscayachi, Rosado INIA, Uruguay LB-13, CAR, Rojo Maipú, Rosado nortino IR, Morado Ruso y Rosado Camiña), while others do not do so (California Late, Calle Chica, Ruso Coyhaique, Chol Chol, Pircunche, Los Boldos, Carrarreñi and Quepe) (Matus et al., 1998). 
The second group clustered 21 clones (16.9\%), with a relatively higher RAPD diversity compared with the first group. However, the genetic diversity level is still very low, since the percentage of the similarity ranged between 94 and $98 \%$ (Figure 2). Clones of different origin and with variable phenotypic characteristics were also found within this group. Similar to the first group, clones that always emit a floral stalk (Uruguay GLB and Camiña Va-llenar), and others do not (Blanca Cañete, Huichahue, Blanco Andino, Rondadero, Chile Chico and Rosé de Lautrec) were included in this cluster (Figure 2). A previous analysis with RAPDs discriminated a group of accessions that emitted floral stalk from those that did not (Al-Zahim et al., 1997). This association was not detected in this study and a possible explanation is that different genotypes and RAPD primers were used. This aspect is important, because it has been reported that the emission of a floral stalk is a relatively stable trait (Etoh and Simon, 2002). The cophenetic correlation coefficient between the cophenetic matrix and the original RAPDs data was 0.98 ; this indicates that the original matrix data is well represented in the dendrogram.

The genetic analysis also showed that some clones genetically similar, such as clones Talca and Huichahue, Rosado Copiapino, Uruguay GLB and Uruguay 1A-2 (Figure 2), also show similar phenotypic characteristics. This situation confirms the lack of association between genetic and phenotypic diversity, implying that RAPDs polymorphism is not linked to phenotypic variation, Besides, many agronomic important traits are controlled by a relative small number of genes with an important phenotypic effect but a low representation in the genome, as compared with the molecular markers which, due to their abundance, can represent in a better way the genetic diversity of the material analyzed.

The presence of a greater morphologic variability on agronomic traits in the accessions (Bradley et al., 1996; Pooler and Simon, 1993a; Matus et al., 1998; Ipek et al., 2003; Volk et al., 2004) as compared to the molecular data can be explained because these two kinds of data have probably been subjected to different evolutionary factors. The phenotypic variability presented by this species could be explained by an intense selection pressure on the species during the domestication process. The better the selected characteristic adapts to the environment, the greater it is the probability to sur- vive in time (Gepts, 2004). For instance, those characteristics having high heritability can cause a strong impact on the maintenance of phenotypic diversity. Figliuolo et al. (2001) determined high heritability values, over $60 \%$, for plant height. Besides, they indicated that plant height is strongly correlated to the bulb weight and its diameter. It seems that two types of garlic have been selected over time, one with a high number of small cloves per bulb and another with larger size and less cloves per bulb. In spite of this situation, it is possible to find also some accessions with a high number of cloves and a high bulb weight. Other forces that could contribute to the high phenotypic variation are the presence of a possible progenitor (A. longicuspis) which reproduces sexually (Koul et al., 1997), infection by virus and viroids, high response to different climatic conditions particularly photoperiod and temperature (Bradley et al., 1996; Ipek et al., 2003), mutations (Koul et al., 1997; Volk et al., 2004), somatic crossing-over and somaclonal variation produced through in vitro culture of the clones (Ordoñez et al., 2002).

On the other hand, the genetic uniformity observed at the molecular level in the garlic collection analyzed, agrees with the vegetative reproduction system of the species, the importance to have duplicated clones in the germplasm, and the neutral characteristic of the molecular markers. A study carried out by Rosales-Longo et al. (2007) where 43 garlic accessions of the "chileno" type and 27 of the "criollo" type were analyzed using AFLP, determined that the accessions classified as "chileno" type showed less genetic diversity than the accessions identified as "criollo". Volk et al. (2004) analyzing a garlic collection located at the Plant Introduction Station in Pullman, Washington, U.S.A., detected that $41 \%$ of the clones were duplicated. The strong selection pressure on agronomic characteristics in many cases does not affect the molecular markers that are generally neutral and can be subjected to genetic drift, unless those sequences were linked to these agronomic and/or adaptative traits. This situation also has been observed in the species at the biochemical level. A study carried out in a collection of clones coming from 25 countries by using biochemical markers, determined low isozyme variability for 65 evaluated clones. Apparently, the low variability between garlic groups was only due to the presence of one or a few mutations, which were not accompanied 
Jaccard Coefficient

\begin{tabular}{ccccc}
0.92 & 0.94 & 0.96 & 0.98 & 1.00 \\
$\perp$ & $\perp$ & $\perp$ & $\perp$ & $\perp$ \\
\hline
\end{tabular}

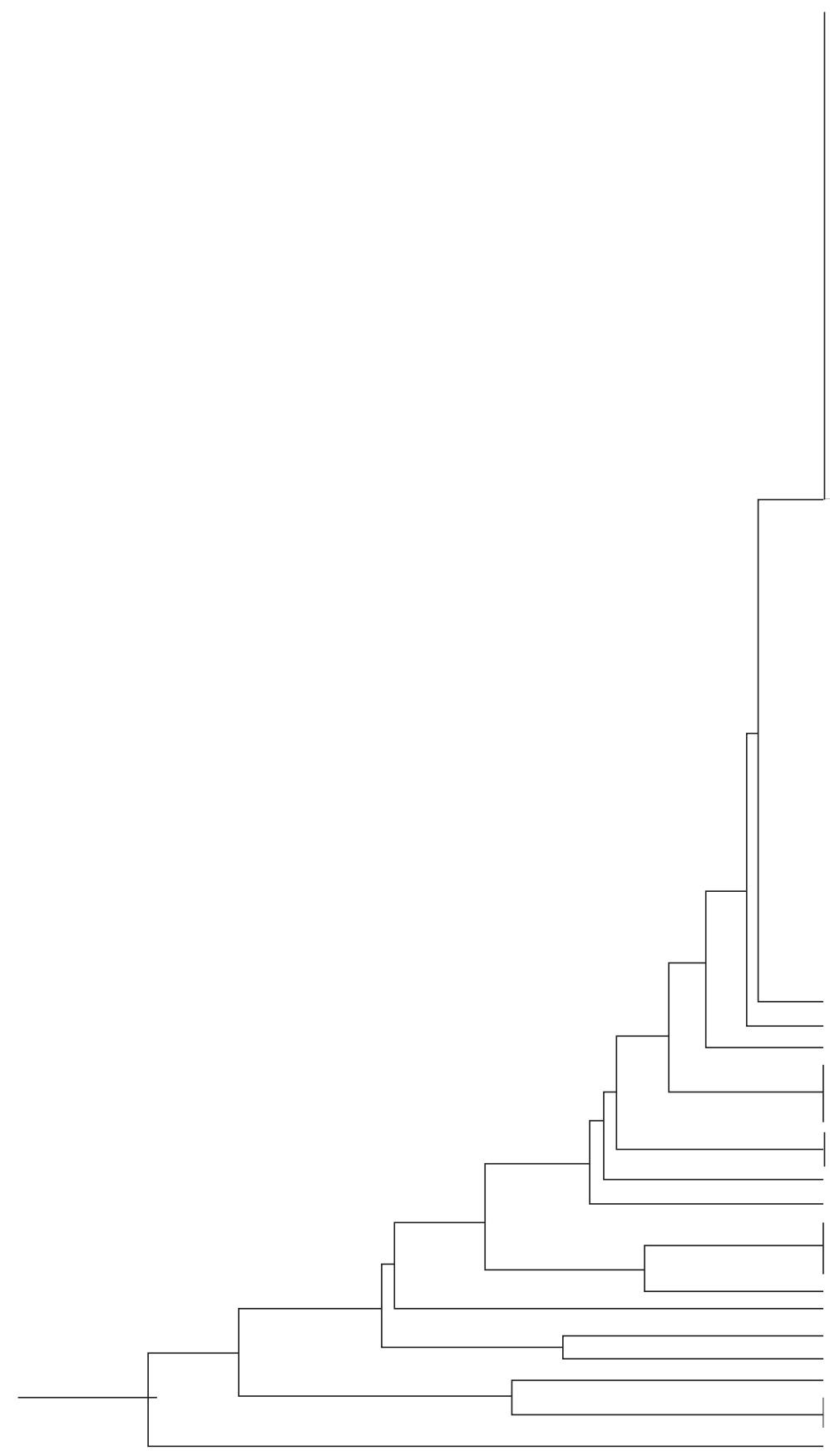

2 Taiwan Kakis

5 Mexicano Criollo

6 Taiwan Básico

7 Nirivilo

9 Mexicano Criollo Kakis B

64 Blanco Imperial

62 California Late

61 Fukuchi White

63 Blanco El Natre

10 Mexicano Blanco Básico

55 Centenario

54 Egipto

53 Rojo Peruano

52 Chino

51 Rosado Argentino Iscayachi

50 Rosado Palqueño

49 Rosado INIA

48 Rosado Marfil Criollo

47 Rosado Criollo Iscayachi

46 Arica

45 Rosado Chillán

44 Uruguay LB-13

43 Uruguay 1A-12

57 Calle Chica

40 Cato

59 Ruso Coyhaique

38 Chol Chol

11 Egipcio Básico

36 Rosado Chileno

14 Blanco Maipú

15 Blanco Mendoza

33 CAR

32 Blanco Argentino Ocoa

16 Blanco Camiña

30 El Palqui

29 Pircunche

28 Los Boldos

27 Carrarreñi

26 Quepe

25 Antofagasta

17 Rojo Maipú

18 Rosado Nortino IR

22 Morado Ruso

19 Rosado Camiña

13 Constitución

68 Blanco Cañete

31 Rosado Argentino

23 Rosado Copiapino

39 Uruguay GLB

42 Uruguay $1 \mathrm{~A}-2$

8 Talca

67 Huichahue

24 Messidrome

56 Rio Grande Calama

58 Blanco Andino

66 Blanco Araucano

65 Blanco Nahuelbuta

69 Rondadero

37 Imperial

34 Camiña Vallenar

35 Chile Chico

3 México Blanco Kakis A

4 Lluteño

21 Rosé de Lautrec

20 Morado Ariqueño

USA

México

México

Chile

USA

Chile

USA

Japón

Chile

México

Brasil

Chile

Chile

China

Bolivia

Bolivia

España

Bolivia

Bolivia

Chile

Chile

Uruguay

Uruguay

Chile

Chile

Chile

Chile

USA

Chile

Chile

Chile

Chile

Argentina

Chile

Chile

Chile

Chile

Chile

Chile

Chile

Argentina

Chile

Chile

Chile

Chile

Chile

Argentina

Chile

Uruguay

Uruguay

Chile

Chile

Francia

Chile

Chile

Chile

Chile

Chile

Chile

Chile

Chile

México

Chile

Francia

Chile

Figure 2. Dendrogram constructed from Random Amplified Polymorphic DNA (RAPD) data of 65 Allium sativum clones collected in Chile. 
by important changes in the rest of the genome (Lallemand et al., 1997).

In absence of the common sexual reproduction system available in garlic, random and induced mutations, polyploids (Volk et al., 2004; Koul et al., 1997) and the production of true seeds (Kamenetsky et al., 2004) could be the only sources of genetic variability available for the breeding programs. The production of true seeds was achieved in Japan (Etoh, 1997), Germany (Konvicka, 1984, cited by Simon, 1993) and the U.S.A. (Pooler and Simon, 1993a; Jenderek and Hannan, 2004). This situation opens a new and a greater possibility for the future genetic improvement of this species (Simon, 1993; Koul et al., 1997), because the sexual reproduction in some garlic accessions could be used as a mean to improve the tolerance to biotic and abiotic conditions, quality and the production of virus-free plants (Kamenetsky et al., 2004).

The low genetic diversity present in the garlic Chilean collection can be partially explained by the origin of the collected material maintained in the Germplasm Bank. This collection is composed with accessions collected in America (Chile, USA, Mexico, Bolivia, Uruguay, Argentine), Europe (Spain, France) and Asia (China, Japan), and does not have genetic material from the center of origin or diversity of the species. Besides, it is most probable that the material naturalized in Chile was previously introduced from one of the countries mentioned before and not directly from the center of origin of the species (Central Asia). Therefore, the possibility of selecting superior clones within this germplasm is low, therefore it is very important to expand the sources of origin of the Chilean germplasm. The reduction of the genetic diversity during the domestication and dissemination process of a crop is widely accepted (Gepts, 2004; Zeder et al., 2006). The magnitude of the bottleneck depends on the number of individuals in the foundational population and the duration of this process (Lallemand et al., 1997; Zeder el al., 2006). This phenomenon has been measured by biochemical (isozymes, storage proteins) and molecular markers such as RFPL, RAPD, AFLP and sequencing DNA data (Hyten et al., 2006). For instance, in garlic Etho et al. (2001) detected a greater genetic diversity among the garlic accessions collected in Central Asia, the primary center of origin of the species, compared with those collected outside of the center.
The fact that there is no association between the genetic diversity of the garlic naturalized in Chile and the site of collection may be due to the exchange of genetic materials among the different geographic zones. In addition to, the agro-climatic situations are not contrasting enough for the natural and artificial selection processes could favor new clones adapted to specific regions of the country. This lack of correlation between genetic diversity and site of collection was also obtained by Ipek et al. (2003) and Volk et al. (2004).

Although there is low genetic diversity as detected by the RAPD, this molecular marker could be used to identify some of these clones. This information could be quite useful to complement the morphologic and agronomic information necessary for the registration of some of these clones, maintain the purity of the variety and protect the breeders'rights of some of the selections. However, to improve the identification process of these clones it is necessary to incorporate another type of molecular markers which would allow the detection of greater genetic differences among clones. Ipek et al. (2003) and Volk et al. (2004) pointed out that the AFLPs could be useful to differentiate garlic clones that had not been individualized by RAPD and isoenzymes. However, Ipek et al. (2003) indicated that both molecular markers (RAPD and AFLP) showed 96\% correlation, grouping the same accessions in similar clusters.

\section{CONCLUSIONS}

1. The molecular analysis by the RAPDs technique detected a low genetic diversity in the garlic germplasm present in Chile.

2. No specific relationship was detected between the patterns generated by the primers employed and the geographic origin of the clones.

3 . There was no clear association between morphologic diversity and genetic diversity detected by RAPDs.

\section{ACKNOWLEDGMENTS}

The authors wish to thank the financing of the INIA to develop this research and to Ms. Patricia Herrera for her collaboration in the sampling of the evaluated germplasm. 


\section{Escasa diversidad genética entre accesiones de ajo (Allium sativum $\mathrm{L}_{\text {.) }}$ detectada mediante ADN Polimórfico Amplificado al Azar (RAPD)}

\author{
R E S U M E N
}

El ajo (Allium sativum L.) es una especie de propagación vegetativa, que presenta una amplia variabilidad morfológica. Los clones de esta especie tienen una adaptación específica a diferentes regiones agroclimáticas. El objetivo de este estudio fue determinar la diversidad genética existente en 65 clones de ajos colectados en Chile e introducidos desde diferentes países, utilizando RAPD (ADN Polimórfico Amplifi- cado al Azar). Para esta evaluación se utilizaron 40 partidores de 10 mers. Los partidores generaron entre dos y 20 bandas, observándose un alto número de patrones con bandas múltiples. Los fragmentos generados difieren en su tamaño entre 3.200 y 369 pb. Los partidores generaron 398 bandas, de las cuales un $87 \%$ fueron polimórficas. El análisis estadístico realizado detectó una similitud genética alta, de un $94 \%$ entre las accesiones evaluadas, donde aproximadamente un $70 \%$ de los clones formaron un grupo homogéneo. Sin embargo, este grupo incluye clones que presentan diferentes características agronómicas.

Palabras clave: Allium sativum, germoplasma, diversidad genética, RAPD.

\section{LITERATURE CITED}

Adams, R.P., and L.H. Rieseberg. 1998. The effects of non-homology in RAPD bands on similarity and multivariate statistical ordination in Brassica and Helianthus. Theor. Appl. Genet. 97:323-326.

Al-Zahim, M., H.J. Newbury, and B.V. Ford-Lloyd. 1997. Classification of genetic variation in garlic (Allium sativum $\mathrm{L}$.) revealed by RAPD. HortScience 32:11021104.

Bark, O.H., and M.J. Havey. 1995. Similarities and relationships among populations of the bulb onion as estimated by nuclear RFLPs. Theor. Appl. Genet. 90:407-414.

Becerra-Velásquez, V., and P. Gepts. 1994. RFLP diversity of common bean (Phaseolus vulgaris L.) in its centres of origin. Genome 37:256-263.

Bradley, K.F., M.A. Rieger, and G.G. Collins. 1996. Classification of Australian garlic cultivars by DNA fingerprinting. Aust. J. Exp. Agric. 36:613-618.

Del Pozo, A., M.I. González, and C. Barraza. 1997. Phenological development of 13 clones of garlic (Allium sativum): influence of temperature, photoperiod and cold storage. Acta Hort. (ISHS) 443:389-394.

D'Ennequin, M., O. Panaud, T. Robert, and A. Ricroch. 1997. Assessment of genetic relationships among sexual and asexual forms of Allium cepa using morphological traits and RAPD markers. Heredity 78:403-409.

Dubouzet, J.G., and K. Shinoda. 1999. Relationships among old and new world Alliums according to ITS DNA sequence analysis. Theor. Appl. Genet. 98:422-433.

Etoh, T. 1997. True seeds in garlic. Acta Hort. (ISHS) 433:247-255.
Etoh, T., and P.W. Simon. 2002. Diversity, fertility and seed production of garlic. p. 101-117. In Rabinovitch, H.D., and L. Currah (eds.) Allium crop science: Recent advances. CABI Publishing, Wallingford, UK.

Etoh, T., H. Watanabe, and S. Iwai. 2001. RAPD variation of garlic clones in the center of origin and the westernmost area of distribution. Mem. Fac. Agr. Kogoshima Univ. 37:21-27.

Figliuolo, G., V. Candido, G. Logozzo, V. Miccoli, and P.L. Spagnoletti-Zeuli. 2001. Genetic evaluation of cultivated garlic germplasm (Allium sativum L. and A. ampeloprasum L.). Euphytica 121:325-334.

García Lampasona, S., L. Martinez, and J.L. Burba. 2003. Genetic diversity among selected Argentinean garlic clones (Allium sativum L.) using AFLP (Amplified Fragment Length Polymorphism). Euphytica 132:115-119.

Gepts, P. 2004. Crop domestication as a long-term selection experiment. In J. Janick (ed). Plant Breed. Rev. 24:1-44.

Hanelt, P. 1990. Taxonomy, evolution, and history. p. 126. In Rabinovitch, H.D., and J.L. Brewster (eds.) Onions and allied crops. Vol. 1. Botany, physiology, and genetics. CRC, Boca Raton, Florida, USA.

Hyten, D.L., Q. Song, Y. Zhu., I.Y. Choi, R.L. Nelson, J.M. Costa, et al. 2006. Impacts of genetic bottlenecks on soybean genome diversity. PNAS 103:1666616671. Available at http://www.pnas.org/cgi/doi/ 10.1073/pnas.0604379103 Accessed March 2007.

Ipek, M., A. Ipek, S.G. Almquist, and P.W. Simon. 2005. Demonstration of linkage and development of the first low-density genetic map of garlic, based on AFLP markers. Theor. Appl. Genet. 110:228-236. 
Ipek, M., A. Ipek, and P. Simon. 2003. Comparison of AFLPs, RAPD markers, and isozymes for diversity assessment of garlic and detection of putative duplicates in germplasm collections. J. Amer. Soc. Hort. Sci. 128:246-252.

Ipek, M., A. Ipek, and P. Simon. 2006. Sequence homology of polymorphic AFLP markers in garlic (Allium sativum L.). Genome 49:1246-1235.

Jenderek, M.M., and R.M. Hannan. 2004. Variation in reproductive characteristics and seed production in the USDA garlic germplasm collection. HortScience 39:485-488.

Jones, H.A., and L.K. Mann. 1963. Onions and their Allies. 286 p. Leonard Hill Books, London, UK.

Jones, R., and H. Rees. 1968. Nuclear DNA variation in Allium. Heredity 23:591-605.

Kamenetsky, R., I. London Shafir, M. Baizerman, C. Kik, F. Khassanov, and H.D. Rabinowitch. 2004. Garlic (Allium sativum L.) and its wild relatives from Central Asia: evaluation for fertility potential. Acta Hort. (ISHS) 637:83-91.

Kirk, J.T., O.H. Rees, and G. Evans. 1970. Base composition of nuclear DNA within the genus Allium. Heredity 25:507-512.

Koul, A.K., R.N. Gohil, and A. Langer. 1997. Prospects of breeding improved garlic in the light of its genetic and breeding systems. Euphytica 28:457-464.

Lallemand, J., C.M. Messian, F. Briand, and T. Etoh. 1997. Delimitation of varietal groups in garlic (Allium sativum L.) by morphological, physiological and biochemical characters. Acta Hort. (ISHS) 433:123132.

López, A., C. Rigoni, V. Silvestri, and J. Burba. 1997. Genetic variability estimation and correlations in white clonal type garlic (Allium sativum L.) characters. Acta Hort. (ISHS) 433:279-283.

Maaß, H.I., and M. Klaas. 1995. Infraespecific differentiation of garlic (Allium sativum L.) by isozyme and RAPD markers. Theor. Appl. Genet. 91:89-97.

Mantel, N.A. 1967. The detection of disease clustering and a generalized regression approach. Cancer Res. 27:209-220.

Matus, I., M.I. Gonzalez, and A. Del Pozo. 1998. Evaluation of phenotypic variation in a Chilean collection of garlic (Allium sativum L.) clones using multivariate analysis. Plant Gen. Res. Newsl. 117:3137.
McCollum, G.D. 1987. Onion and allies. p. 186-190. In N.W. Simmonds (ed.) Evolution of crop plants. Longman S. \& T., London, England.

Ordoñez, A., L.E. Torres, M.G. Hidalgo, y J.O. Muñoz. 2002. Análisis citológico de una variante genética somática de ajo (Allium sativum L.) tipo rosado. Agriscientia 19:37-43.

Ovesna, J., L. Lucera, J. Kralova, L. Leisova, H. Stavelikova, and J. Velisek. 2007. Genetic diversity among garlic clones as revealed by AFLP, phenotypic descriptors and S-aminoacid level. Vegetable Crop Res. Bull. 66:105-116.

Pooler, M.R., and P.W. Simon. 1993a. Characterization and classification of isozyme and morphological variation in a diverse collection of garlic clones. Euphytica 68:121-130.

Pooler, M.R., and P.W. Simon. 1993b. Garlic flowering in response to clone, photoperiod, growth temperature, and cold storage. HortScience 28:1085-1086.

Ranjekar, P.K., D. Pallota, and J.G. Lafontaine. 1978. Analysis of plant genomes. V. Comparative study of molecular properties of DNAs of seven Allium species. Biochem. Genet. 16:967-970.

Rohlf, F.J. 2000. NTSYS-PC Numerical taxonomy and multivariate analysis system. Version 2.1. Manual. Applied Biostatistics, New York, USA.

Rosales-Longo, F.U., y L.G. Molina-Monterroso. 2007. Diversidad genética de poblaciones de ajo (Allium sativum L.) cultivadas en Guatemala, definida por marcadores de ADN. Agronomía Mesoamericana 18:85-92.

Simon, P.W. 1993. Breeding carrot, cucumber, onion and garlic for improved quality and nutritional value. Hort. Bras. 11:171-173.

Sneath, P.A., and R.R. Sokal. 1973. Numerical taxonomy: the principles and practice of numerical classification. 573 p. Freeman, San Francisco, California, USA.

Volk, G.M., A.D. Henk, and C.M. Richards. 2004. Genetic diversity among U.S. garlic clones as detected using AFLP methods. J. Amer. Soc. Hort. Sci. 129:559-569.

Wilkie, S., P.G. Isaac, and R.J. Slater. 1993. Random amplified polymorphic DNA (RAPD) markers for genetic analysis in Allium. Theor. Appl. Genet. 86:497-504.

Zeder, M.A., E. Emshwiller, B.D. Smith, and D.G. Bradley. 2006. Documenting domestication: the intersection of genetics and archeology. Trends Genet. 22:138-155. 